\title{
Low-carbon strategies towards 2050: Comparing ex-ante policy evaluation studies and national planning processes in Europe
}

\author{
Mariësse A.E. van Sluisveld ${ }^{\mathrm{a}, \mathrm{b}, *}$, Andries F. Hof ${ }^{\mathrm{a}, \mathrm{b}}$, Detlef P. van Vuuren ${ }^{\mathrm{a}, \mathrm{b}}$, Pieter Boot $^{\mathrm{b}}$, \\ Patrick Criqui $^{\mathrm{c}, \mathrm{d}}$, Felix C. Matthes ${ }^{\mathrm{e}}$, Jos Notenboom ${ }^{\mathrm{b}}$, Sigurd L. Pedersen ${ }^{\mathrm{f}}$, Benjamin Pfluger ${ }^{\mathrm{g}}$, \\ Jim Watson ${ }^{\text {h,i }}$
}

a Copernicus Institute of Sustainable Development, Utrecht University, Utrecht, The Netherlands

b PBL Netherlands Environmental Assessment Agency, The Hague, The Netherlands

c GAEL-EDDEN, Laboratoire Économie du développement durable et de l'énergie, Grenoble, France

d CNRS, Centre National de la Recherche Scientifique, Paris, France

e Öko-Institut, Berlin, Germany

${ }^{f}$ Danish Energy Agency, Copenhagen, Denmark

${ }^{g}$ Fraunhofer-Institut für System- und Innovationsforschung (ISI), Karlsruhe, Germany

${ }^{\text {h }}$ UK Energy Research Center (UKERC), London, United Kingdom

${ }^{i}$ Science Policy Research Unit (SPRU), University of Sussex, Brighton, United Kingdom

\section{A R T I C L E I N F O}

\section{Keywords:}

Climate and energy policy

Decarbonisation strategies

Ex-ante policy evaluation

Integrated assessment modelling

\begin{abstract}
A B S T R A C T
The European Union (EU) is committed to reducing its greenhouse gas (GHG) emission levels by $80 \%-95 \%$ in 2050 compared to 1990 levels. Various approaches have been developed to secure and evaluate the progress made towards this objective. To gain insights into how EU Member States are aligning to this collective longterm objective, we systematically compare the planning and ex-ante evaluation processes for five EU countries (respectively Denmark, France, Germany, the Netherlands and the United Kingdom). The comparative analysis consists of a qualitative comparison of (1) the governance of long-term policy planning and evaluation processes, (2) the national arrangement for quantitative (model-based) ex-ante policy evaluation and (3) the national arrangement for qualitative ex-ante policy evaluation (stakeholder participation). In a second step we conduct a quantitative comparison of national model-based ex-ante evaluation studies to assess the relative differences between the considered routes and the differences across the various countries. Although the five Member States plan policies along the same EU objective, we find a high diversity in how long-term commitments are established, governed and evaluated on the national level. Model-based scenario analyses are commonly used to explore and evaluate the possible national routes towards the EU 2050 objective. However, as these processes mostly concentrate on domestic action, they pay little attention to how domestic policies are affected by, or affecting, other international activities throughout Europe. Hence, current findings suggest that cross-border collaboration and stakeholder participation could further strengthen the analytical understanding of required transformative change in Europe and subsequently lead to a more durable long-term solution over time.
\end{abstract}

\section{Introduction}

The European Union (EU) is committed to reducing its greenhouse gas (GHG) emission levels by $80 \%-95 \%$ in 2050 compared to 1990 levels. In order to track the progress of Member States in mitigating their GHG emissions, the EU has established various regulations and reporting obligations to monitor the current trends (ex-post evaluation) and provided guidelines to articulate on prospective trends (ex-ante evaluation) (EC, 2004). Most of the established monitoring and reporting practices have been oriented towards the documentation of (national) GHG emissions and the implemention of the Kyoto Protocol (European Union, 2013). However, since the adoption of the '2020 Climate and Energy package' in 2009 (European Union, 2009a,b,c), which introduced new policies and legally binding legislations for the year 2020, new challenges for monitoring and reporting have arisen. For example, the EU Renewable Energy Directive (RED), as one of the new policies in the 'Climate and Energy package', has been translated into various National Renewable Energy Action Plans (NREAPs), which

\footnotetext{
* Corresponding author at: PBL Netherlands Environmental Assessment Agency, The Hague, The Netherlands.

E-mail address: m.a.e.vansluisveld@gmail.com (M.A.E. van Sluisveld).
} 
outline the considered routes towards realising the national renewable energy ambitions by 2020. Likewise, Member States have adopted national (non-binding) commitments on total primary or final energy consumption as part of the EU Energy Efficiency Directive (EED) (EEA, 2014). As a result, these specific ambitions and commitments have been monitored and evaluated over time.

As these targets for 2020 need to be seen in a broader context of meeting long-term ambitions, such as the pledged commitments for 2030 (GHG emission reductions of $40 \%$ compared to 1990) (European Commission, 2014), 2050 (GHG emissions reductions of $80 \%-95 \%$ compared to 1990) or the end of the century (well below $2{ }^{\circ} \mathrm{C}$ ) (European Commission, 2011), the planning, coordination and documentation efforts of both the EU and the Member States need to be improved. This is acknowledged in the EU 2030 framework (European Commission, 2014), in which the European Commission proposed a new governance scheme to enhance the insights into the alignment of Member States to various long-term objectives (European Commission, 2016). Hence, along the EU 2030 framework, the EU has established the 'Energy Union' to streamline and integrate the various co-existing policy frameworks into one cohesive strategy. As part of this, Member States are asked to prepare national energy and climate plans with quantified detail towards 2030 and a more in-depth perspective towards 2050. These plans are intended to warrant the consistency of national commitments to the various long-term EU policy objectives (European Commission, 2015).

Given the overall recent nature of planning towards 2050 on the national level, we present an overview in this paper of the various activities undertaken by the EU Member States to steer towards this goal. As such, the main research questions of this study are as follows:

- How are ex-ante planning and evaluation processes organised across different European countries?

- Are existing representative national scenarios consistent with the long-term European policy objective for 2050?

We focus on five EU Member States (respectively Denmark, France, Germany, The Netherlands and the United Kingdom) which together account for 52\% of total GHG emissions in the EU in 2014 (EEA, 2016). As such, the collective movement of these governments is considered important in the light of meeting the EU 2050 objective. Given how several north-western European countries have driven the EU climate policy agenda in the past (e.g. Germany and the United Kingdom) (Jordan and Liefferink, 2004), it provides an experience base to which other countries can be compared and contrasted.

\section{Methodology}

\subsection{Qualitative evaluation of national long-term planning and evaluation processes}

To qualitatively evaluate how long-term planning processes for climate and energy policy have been embedded in various national policy contexts, we draw a typology based on three elements that have been recognized in political science literature as contributing to lasting policy stability (see Hovi et al. 2009, p.29). These three elements are interpreted in this study as (1) the institutional and procedural arrangements for long-term planning, (2) the national arrangement for quantitative (model-based) ex-ante policy evaluation and (3) the engagement of (public) stakeholders in national planning or evaluation processes. To frame the selected countries along this typology we have drawn insights from literature, extracting information from national and European policies and regulations or research papers on long-term policy evaluation. Additional insights have been drawn from an expert workshop inviting national policy makers and experts familiar with policy planning and ex-ante policy evaluation processes (van Sluisveld et al., 2016).

\subsection{Quantitative evaluation of ex-ante (model-based) policy evaluation}

Various tools are available to assess the appropriateness of longterm strategies in a consistent and quantitative manner, ranging from very simple tools (e.g. checklists, decisions trees) to very complex tools and methods (e.g. cost-benefit analysis, risk analysis and scenario analysis via computer-based models linking empirical relationships in mathematical formulas) (Nilsson et al., 2008). As model-based scenario analysis has been the most frequently used method in climate policy assessment (Wei et al., 2015), we compare a variety of existing modelbased scenario studies to evaluate the planned policy directions across the five EU Member States.

We distinguish between two types of model-based scenario analysis types; those designed to study the developments on a national level (national model-based scenario studies) and those designed to study national developments in a broader European context (European model-based scenario studies). The former category can represent the long-term perspective of a single EU Member State in great detail, whereas the latter category can employ a consistent evaluation method across the full range of EU Member States. In the following sections we will describe both categories in more detail.

\subsubsection{National model-based scenario studies}

As quantitative ex-ante evaluation studies in line with the national 2050 ambitions are yet to be submitted within the context of the Energy Union, we draw insights from existing model-based scenario studies. For practical reasons, we have selected one representative national model-based study per country. To warrant the representativeness of these studies, we have specifically selected studies that (1) are conducted relatively recently, (2) include one or more policy scenarios in line with the EU 2050 ambitions and (3) could be regarded as studies with a high formal status (authoritative) in each country (see Table 1 for an overview).

For Denmark, we have selected the multi-pathway assessment of the Danish Energy Agency (2014). Studies by the Danish Energy Agency (DEA) can be considered as authoritative, as national model-based analyses by the DEA are usually subjected to approval processes that involve the minister and various stakeholders and research institutes. Moreover, all scenarios in this study aim for a fossil-fuel independent energy system, which is consistent with the current policy direction of Denmark.

For France, we focus on the four marker scenarios that have been identified during the National Debate on the Energy Transition (DNTE) in 2013 (Grandjean et al., 2014). The marker scenarios represent four stylised pathways that meet the French GHG emission reduction target of $75 \%$ by 2050 . The scenarios differ in focus on how the French energy system is to be transformed (varying in terms of high and low energy

Table 1

Overview of resources used and their defining characteristics.

\begin{tabular}{|c|c|c|c|c|c|}
\hline & Denmark & France & Germany & The Netherlands & United Kingdom \\
\hline Contributing Institute(s) & Danish Energy Agency & ANCRE & Öko-Institut Fraunhofer-ISI & $\mathrm{PBL} / \mathrm{CPB}$ & UCL/UKERC \\
\hline Mitigation scenarios [number consistent with EU 2050 goal] & $4[4]$ & $4[4]$ & $2[2]$ & $4[2]$ & $5[2]$ \\
\hline Year of publication & 2014 & 2014 & 2016 & 2015 & 2016 \\
\hline
\end{tabular}


Table 2

Overview of national policy planning contexts and ex-ante evaluation configurations per country.

\begin{tabular}{|c|c|c|c|c|c|}
\hline & Denmark & France & Germany & The Netherlands & United Kingdom \\
\hline \multicolumn{6}{|c|}{ Governance of long-term policy planning and evaluation processes } \\
\hline 2050 policy plan (year of publishing) & $\begin{array}{l}\text { Energy Strategy } \\
2050(2011)\end{array}$ & $\begin{array}{l}\text { National Low-carbon } \\
\text { Strategy (2015) }\end{array}$ & Climate Plan 2050 (2016) & Energy Agenda (2016) & Carbon Plan (2011) \\
\hline $\begin{array}{l}\text { Institutional arrangement for long-term } \\
\text { ambitions (Year of adoption) }\end{array}$ & $\begin{array}{l}\text { Climate Change } \\
\text { Act (2014) }\end{array}$ & $\begin{array}{l}\text { Energy Transition for Green } \\
\text { Growth Act (2015) }\end{array}$ & $\begin{array}{l}\text { None (but decisions require } \\
\text { inter-ministerial approval) }\end{array}$ & None (proposed) & $\begin{array}{l}\text { Climate Change } \\
\text { Act (2008) }\end{array}$ \\
\hline Advising body (year of establishment) & CCC (2015) & CETE (2015) & $\begin{array}{l}\text { No (but inter-ministerial } \\
\text { approval) }\end{array}$ & $\begin{array}{l}\text { No (but part of 'planning } \\
\text { agencies') }\end{array}$ & CCC (2008) \\
\hline \multicolumn{6}{|c|}{ National arrangement for quantitative (model-based) ex-ante policy evaluation } \\
\hline $\begin{array}{l}\text { Formal position in policy design and } \\
\text { evaluation }\end{array}$ & Yes & Yes & strategic planning & strategic planning & Yes \\
\hline Government institutes & Yes & Yes & No & Yes & Yes \\
\hline Academic institutes & Yes & Yes & Yes & No & Yes \\
\hline Other institutes & Yes & Yes & Yes & Yes & Yes \\
\hline \multicolumn{6}{|c|}{ National arrangement for qualitative ex-ante policy evaluation } \\
\hline Public dialogue (Year) & Yes (2009) & Yes (2013) & Yes (2015) & Yes (2015) & Yes (2011) \\
\hline
\end{tabular}

demand reduction, and high and low shares for nuclear energy in total power supply).

As a representative German national scenario study, we have selected the "Climate protection scenario 2050" study (Öko-Institut/ Fraunhofer ISI, 2016). The policy scenarios within this study have been commissioned by the Federal Ministry for the Environment, Nature Conservation, Building and Nuclear Safety (BMUB) and developed in a research consortium as part of a broader (iterative) modelling exercise (see e.g. Öko-Institut/Fraunhofer ISI, 2014, 2015,2016). We specifically select the two scenarios that aim for a $80 \%$ and 95\% GHG emission reduction by 2050 relative to 1990 levels. The two scenarios do not deploy nuclear energy and carbon capture and storage (CCS) technologies in power supply.

As a representative Dutch national scenario study, we have selected the 'Toekomstverkenning Welvaart en Leefomgeving' (WLO) study (Manders and Kool, 2015). The scenarios in the WLO study have been commissioned by the Ministry of Economic Affairs and the Ministry of Infrastructure and Environment and have provided the analytical underpinning for the Dutch long-term low-carbon vision for 2050 as presented in the Energy Agenda (Ministry of Economic Affairs, 2016). The two scenarios in the WLO study that align to the EU 2050 ambitionadopt different assumptions on how electricity is supplied (centralised or decentralised power supply) (Matthijsen et al., 2015).

For the United Kingdom (UK) we have selected the scenarios by McGlade et al. (2016) as representative national scenarios for this study. These scenarios respect official UK short-term and long-term targets on emission reductions and have been produced by the same model (UKTM) as used to advice the UK government on the allowable carbon budget for the 2028-2032 period (fifth carbon budget) (Committee on Climate Change, 2016; Pye et al., 2015). The selected policy scenarios (respectively Maintain and Maintain (Tech fail)) are in line with the $80 \%$ GHG emission reduction target, albeit with different technology availability assumptions. The Maintain scenario embeds explicit restrictions on new capital construction for coal over time, while Tech Fail restricts the commercialisation of carbon capture and storage (CCS) technologies in the near future (Maintain (tech fail)). One unpublished additional scenario of the same modelling exercise has been included (Late catch-up) which reflects a temporary failure to remain aligned to the pledged long-term national climate ambitions.

\subsubsection{European model-based scenario studies}

Complementary to the national model-based scenario studies, we also include the outcomes of several European model-based scenario studies. For this study we draw from the multi-model intercomparison project EMF28 (Weyant et al., 2013); a project by the Energy Modelling Forum that specifically focused on the European policy context and the interplay between EU Member states. Multiple energy-economy models have participated within this project to quantitatively assess a wide range of futures under harmonised assumptions on future climate policy and technological availability.

For this study we have selected one specific scenario narrative that is consistent with the EU 2050 objective, devising optimistic assumptions on multilateral cooperation, market functioning, technological availability, technological development and efficiency improvement (denoted as "80\% EFF" in Knopf et al. (2013)). Given differences in the geographical, temporal and parametric coverage of the partaking computational models, only eight models have been able to provide quantitative detail on the five EU Member States included in this study. ${ }^{1}$

\section{Results}

\subsection{Qualitative evaluation of national long-term policy planning}

In the following section we present the typology on long-term planning for climate and energy policy within the national contexts of five EU Member States. The results have been summarised in Table 2.

\subsubsection{Governance of long-term policy planning and evaluation processes}

The five north-western European countries included in this study have a history in formulating and institutionalising policy objectives over various periods of time. However, procedural differences in longterm planning have been observed across the five Member States. This is most notably observed in the embedment of 2050 ambitions in policies and regulations and the presence or absence of routinised evaluation processes.

Denmark has a history in drawing up long-term strategies and underpinning strategic decisions with model-based analysis. However, only since the establishment of the Climate Change Act (2014), ex-ante policy evaluations have become more formally embedded within national climate policy planning processes. This is also reflected in the founding of a Danish Council on Climate Change (CCC), which is responsible for the continuous evaluation of the national movements towards meeting the national climate objectives and international climate commitments. The Danish CCC may also advise on further needed action (Sørensen et al., 2015).

The French long-term climate and energy ambition has been embedded in the POPE-law since 2005 (75\% GHG emission reductions by

\footnotetext{
${ }^{1}$ Respectively PET, POLES, PRIMES, TIMES PanEU, FARM EU, GEM-E3, TIAM-UCL, TIMES-VTT. The former four models consistently provide information for all studied EU Member States, whereas the latter four provide information on more selective national levels. FARM EU and POLES are models with global coverage, whereas PET, TIMES PanEU and PRIMES are European energy sector models (Knopf et al., 2013).
} 
2050 compared to 1990, also denoted as "factor 4"). Additional details and intermediate objectives towards this goal have been adopted in the Energy Transition for Green Growth Act (2015) (Loi de Transition Énergétique pour la Croissance Verte, LTECV) (Ministry of Ecology Sustainable Development and Energy, 2015a). The LTECV also formalised the establishment of a rotating independent expert committee (Comité d'experts pour la transition énergétique, CETE). This expert committee is appointed for two years at a time to assess the progress made in implementing the national low-carbon strategy (Ministry of Ecology Sustainable Development and Energy, 2015b).

Germany recently established the Climate plan 2050 (BMUB, 2016a), which outlines the national low-carbon strategy up to 2050. The plan builds on the knowledge of a number of long-term model-based scenario analyses which have been commissioned by many different (non-) governmental stakeholders over the last few years (see for an overview Fabra et al., 2015; Haller et al., 2015; Hillebrandt et al., 2015). The "Climate Protection Scenario 2050", also selected in this study, most likely played a crucial role in the planning process, as (1) it reports on emissions of energy use and all other GHG sources and (2) reflects existing climate policies and ministerial preferences (such as a nuclear phase-out, the availability of carbon removal technologies for process industry only and limiting the deployment of biomass via the "access rights concept"). Although the German national long-term climate ambitions are not explicitly legislated, appropriate policies and longterm strategies are implemented via established inter-ministerial approval procedures.

Dutch climate policy has so far lacked a clear and ambitious longterm perspective, with policy planning and evaluation efforts mostly focused at fleshing out short-term ambitions (Faber et al., 2016). For example, the Dutch Ministry of Economic Affairs has a history in commissioning model-based policy assessments of current and planned policies (see e.g. Daniels and Kruitwagen, 2010; Schoots et al. 2016). These model-based policy assessments, however, do not stretch out beyond the 2020-2035 period. Some perspective towards 2050 is offered in the Energy Agenda (2016) via indicative (linear) pathways between 2023 and 2050, describing the leeway between the "extended policy" and "additional policy" and a 80\% GHG emission reduction goal (Ministry of Economic Affairs, 2016). Since January 2017, a proposal for a Climate Change Act has been submitted to the Dutch parliament (Beunderman, 2017), resembling a similar model as utilised in the UK. ${ }^{2}$

In 2008 the United Kingdom enacted the Climate Change Act (Climate Change Act, 2008 (c. 27)) which established an institutional framework for long-term climate policy planning and ex-ante evaluation processes. The Climate Change Act requires the national government to set legallybinding carbon budgets over subsequent periods of time, following advice from the Committee on Climate Change (CCC). The CCC is appointed to propose a carbon budget every five years over the whole period up to 2050 (requiring parliamentary approval) as well as publish regular progress reports (Faber et al., 2016). Quantitative ex-ante evaluation processes are therefore routinely used to underpin strategic energy and climate policy statements and to quantify the carbon budgets for each period.

\subsubsection{National arrangement for quantitative ex-ante policy evaluation}

Model-based assessments have been devised to underpin long-term policy strategies with quantitative evidence across the selected five north-western European countries. Differences have been observed in developing and warranting specialised knowledge and skills in performing quantitative ex-ante climate policy evaluation.

Denmark's modelling skills are spread over a wide variety of institutions partaking in the development of national energy scenarios and computational models, ranging from universities, research

\footnotetext{
${ }^{2}$ Proposing to set legally-binding GHG emission reduction targets while formalising a five-year policy revision cycle and a monitoring authority (Beunderman, 2017)
}

institutes, consultancies and governmental agencies (see e.g. Lund et al. 2011; Mathiesen et al., 2015). Although the ex-ante policy evaluation studies of the Danish Energy Agency are considered the lead contenders in informing Danish policy planning processes, other research groups may be consulted, depending on the focus of each individual analysis.

In France, various research institutes and universities have been united in the French National Alliance for Energy Research Coordination (ANCRE). ANCRE contains a thematic group that embodies modelling and model-based analysis, which has contributed to the development of national energy strategies in the past. As such, the ANCRE alliance has mostly been responsible for providing the analytical underpinning for policy planning processes since its establishment, such as during the nation-wide stakeholder dialogue sessions (DNTE), the LTECV and further outlines of the LTECV in policy (ANCRE, 2016; Argyriou et al., 2016).

In Germany, model-based analysis is outsourced to external independent bodies, such as, amongst others, (non-governmental) research institutes (e.g. Öko-Institut, Fraunhofer-ISI, DLR German Aerospace Centre), consultancies and academia. The German government is therefore accustomed to commissioning ex-ante evaluation studies via calls and tenders, structurally employing consortia of research institutes with specialised knowledge. Although the government has a certain authority over the direction of research and modelling via their funding, it leaves the ex-ante evaluation capabilities unsusceptible to changes in the administration. In the absence of any legal embedding of the long-term climate ambitions in German law, the ex-ante policy evaluation studies have no judicial weight and are only used for strategic planning.

For the Netherlands, only a limited number of national decarbonisation studies have been developed. These studies have predominantly been compiled by the 'planning agencies' of the Dutch government (Janssen et al., 2006; Manders and Kool, 2015) or in collaboration with (energy) research institutes as part of a broader evaluation framework (e.g. PBL/ECN (2011)). The national model-based ex-ante evaluation capabilities are currently mostly used to assess the implications of current and planned policies in the near to medium term (up to 2035).

In the United Kingdom, many of the ex-ante policy evaluation capabilities are held by academic departments, research networks, governmental departments and consultancies (including former government research institutes) (an overview is given in Strachan (2011a,b)). Only a few models are routinely used for long-term policy planning in the UK. During the 2003-2013 period most of the analytical underpinning for long-term climate policy has been drawn from the UK MARKAL family of models (Committee on Climate Change, 2016; Pye et al., 2015; Strachan, 2011a) whereas the UK TIMES model has been used from 2013 onwards (Anandarajah et al., 2013).

\subsubsection{National arrangement for qualitative ex-ante policy evaluation}

In this section we consider participatory processes with (public) stakeholders as a qualitative ex-ante evaluation process. Although various participatory methods exist (see e.g. van Asselt and RijkensKlomp, 2002) we predominantly interpret it in this study as a decisionsupport process that is both linked and complementary to quantitative modelling. Notable differences have been observed across the five north-western European countries, particularly in terms of how participatory processes are utilised in policy planning or evaluation processes.

Denmark has carried out forward looking studies via the use of participatory processes in the past. In 2006 the Danish Association of Engineers (IDA) organised multiple seminars to draw out several longterm perspectives from over 1600 participants. The perspectives have been assessed using the energy system model EnergyPLAN and were presented in the IDA energy plan report (Lund and Mathiesen, 2009). Although such a large-scale participatory process has generated public support for the considered low-carbon strategies, it has mainly been 
used for strategic planning and has not had a formal role in policy.

In France, the national government has taken stock of supported transition pathways via nation-wide stakeholder dialogue sessions (involving academia, industry and NGOs) (DNTE, 2013; Mathy et al., 2015b). Model-based analyses by stakeholders have provided input to these dialogue sessions, leading to the development of four stylised long-term energy transition scenarios. These four scenarios have subsequently been subjected to a multi-criteria assessment in a broader participatory process with stakeholders (a council of 112 members from 7 stakeholders groups), which returned a preference order for the four considered long-term futures. As the legislated objectives closely resemble the outlines of one of the analysed transition pathways, these dialogue sessions are believed to have influenced the shaping of the LTECV (Argyriou et al., 2016; Mathy et al., 2015a; Sartor et al., 2017).

To gain broader societal consensus for the Climate Plan 2050, Germany has consulted over 500 stakeholders within federal states, municipalities, industry, interest groups and civil society via multiple participatory methods (respectively via various on-site and online dialogue sessions with stakeholders and the public). The broader (public) stakeholder engagement delivered 97 climate action measures in service of the national 2050 decarbonisation ambitions, which have been collected and published in the "measurements catalogue" (BMUB, 2016b). The modelling suite used for the "Climate Protection Scenario 2050" supported the (governmental) stakeholder sessions by quantitatively evaluating the proposed measures (BMUB, 2016b). Despite this involvement, the national dialogues have not led to new comprehensive ex-ante evaluation studies or changes to long-term policy.

In 2016 the Dutch government initiated the Energy Debates, inviting multiple governmental representatives, businesses, research institutes and network organisations across the country (representing 72 organisations and 3000 people in total) to share possible solutions towards meeting the climate objectives for 2050. Some stakeholders supported their long-term vision with specifically developed quantitative studies (as found in e.g. Gas Unie (2016)). Although the outcomes of these Energy Debates have been taken into consideration during the formulation of the Energy Agenda (Dutch Government, 2016), the process has remained dissociated from the more routinised (quantitative) policy evaluation methods in the Netherlands (remaining mostly a product of the Dutch 'planning agencies').

In 2010, the United Kingdom launched a public engagement programme to open a public dialogue on how the UK should meet its legally binding targets in 2050. The engagement programme resulted into three local deliberative dialogue sessions utilising the '2050 Energy Calculator' tool, ${ }^{3}$ an online carbon accounting tool developed by the former Department of Energy and Climate Change (DECC). Simultaneously, the broader public was engaged via the 'My2050' serious game interface, ${ }^{4}$ which engaged over 10,000 participants in using a simplified version of the 2050 calculator. The results have been used to inform policy makers about specific preferences, as well as to inform about patterns in the variation of answers, with only limited impact on further policy design (Comber and Sheikh, 2011). Moreover, as the UK government draws insights from a wider range of sources than just the routinely used model-based evaluation tools, it may also consider exante policy studies developed by stakeholders (such as those by the Energy Technologies Institute, a public-private partnership maintaining the ESME-model, and the National Grid, supported by its own in-house model).

\subsection{A quantitative comparison of national ex-ante policy evaluation studies}

To consider which long-term policy directions are being analysed by the five EU Member States, we look at a selective draw of national

\footnotetext{
${ }^{3}$ http://2050-calculator-tool.decc.gov.uk/.

${ }^{4}$ http://my2050.decc.gov.uk/.
}

representative model-based policy evaluation studies. Although the reports written along the selected model-based evaluation studies vary in style and level of provided quantitative detail, a few common metrics have been identified throughout the studies (respectively greenhouse gas emission reductions, the share of renewable energy in electricity production and total primary energy reductions). These common metrics allow for a cross-comparison between the national studies. To gain additional insights into the considered national developments in a broader European perspective, we portray the representative national model-based scenarios together with the European model-based scenarios (see Fig. 1).

In relation to total GHG emission reductions, all studies depict an overall similar GHG emission reduction rate for 2030, fluctuating around 50\% compared to 1990 levels. The national model-based studies are therefore observed to exceed the EU ambitions (40\%) over the nearterm, while broadly abiding by the nationally imposed targets. Interestingly, over time the national policy ambitions show to anchor to the EU 2050 ambitions, with a predominant focus on meeting the lower level in the 80\%-95\% EU 2050 objective. Some exceptions to this rule are found for France (aiming for a 75\% GHG emission reduction as legislated by the LTECV) and Germany (which also explores a pathway towards 95\% GHG emission reductions). However, it should be noted that these conclusions can be considered as rather contentious, given our deliberate choice to only select model-based scenarios aligned to the EU 2050 objective.

We devise the share of renewable energy in electricity production as a first indicator to draw insights on the overall course of development for the power supply sectors for each country. The selective draw in representative national model-based scenario studies yielded a variety of different perspectives on future power system change. Remarkable for Denmark is that the four included representative national scenarios all reflect similar trajectories towards achieving a full renewable power system by 2035. The study thus represents a discussion on the to-be considered resources towards this objective, describing various combinations of wind power, bioelectricity and hydrogen in the electricity mix. Conversely, the French representative national scenarios show a wide range in possible low-carbon transition routes, all designed around different considerations for the current nuclear capital stock. The national model-based scenarios have therefore been used to explore a potential switch from nuclear energy to renewable energy technologies (Grandjean et al., 2014). For Germany, as a result of explicitly exempting technologies such as nuclear and carbon removal (CCS) technologies in power generation for all scenarios, the model-based scenarios show to depict a relatively strong orientation towards renewable energy technologies in power production. Regardless of the climate objective assumed, the German scenarios show to favour the deployment of wind over solar power by 2050 (Öko-Institut/Fraunhofer ISI, 2015). The Netherlands reflects a similar development trajectory for renewable energy technologies in power production as Germany, though adding more weight to bioelectricity use, $\mathrm{CO}_{2}$ removal and demand reduction. The UK scenarios depict a lower renewable energy share in power production over time compared to other countries, partly because the contribution from renewables has been historically one of the lowest in the EU. The depicted scenarios mostly reflect combinations of offshore wind and nuclear power generation.

Large differences are also depicted for reductions in total primary energy demand between countries and between scenarios, ranging from no reduction in demand for one of the French scenarios to more than $50 \%$ reduction in the French and German scenarios. The demand reduction projections may, however, be influenced by (1) the way in which the models are structured (as most techno-economic modelling exercises focus on fuel substitution rather than demand reduction although some explicit assumptions on demand reduction are included in the French scenarios) and (2) a statistical artefact in primary energy accounting (which puts intermittent technologies in a more beneficial position than other decarbonisation technologies). Particularly the 


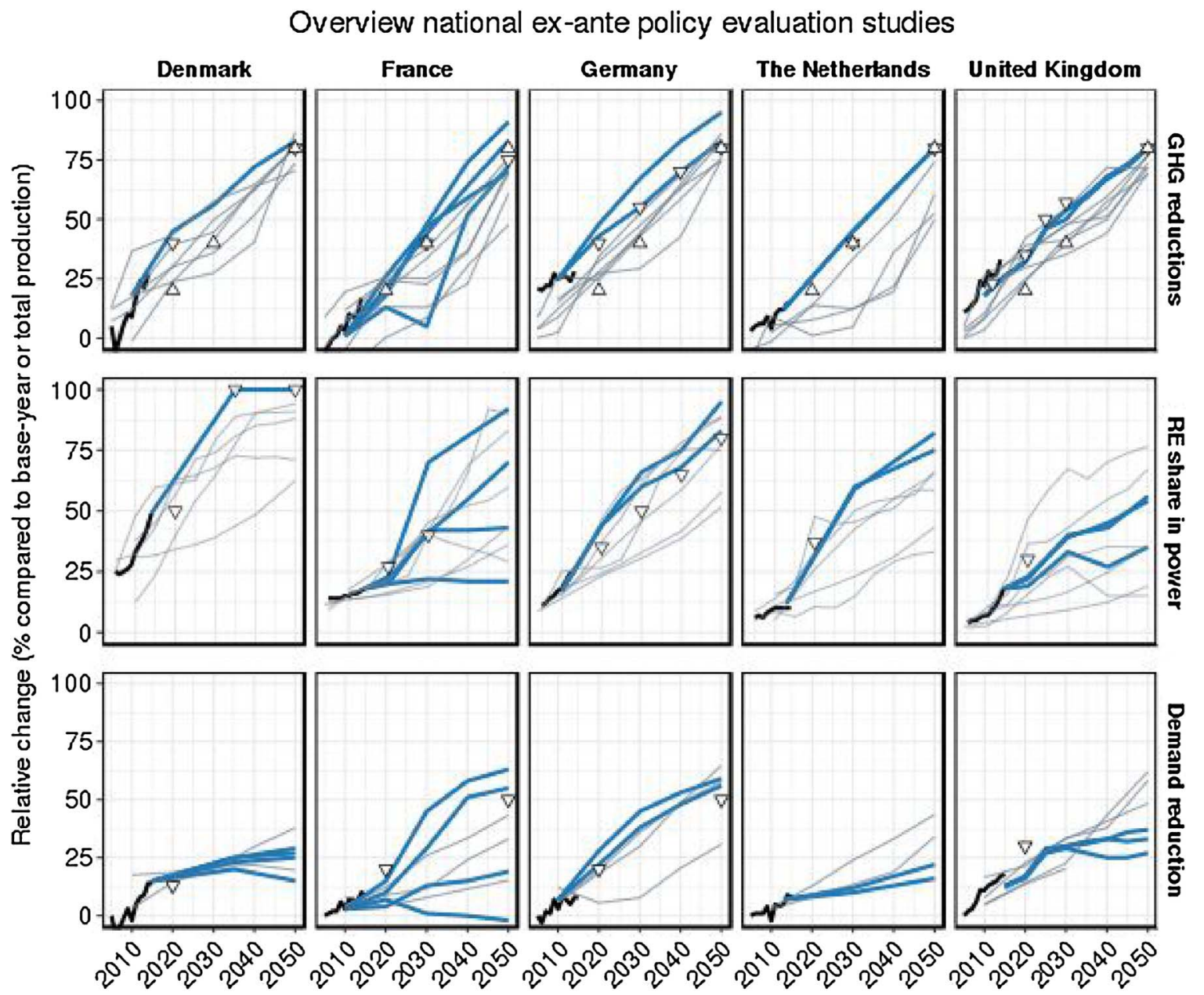

\section{Pollcy target \\ $\therefore$ EU policy target \\ Projections \\ - EMF28 \\ $\rightarrow$ National policy target $\quad$ Historical \\ - National scenarios}

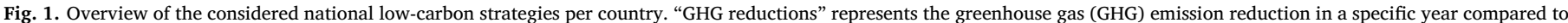

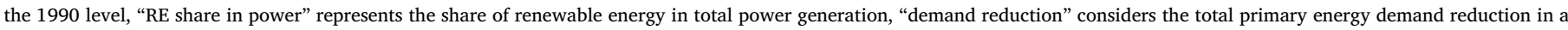

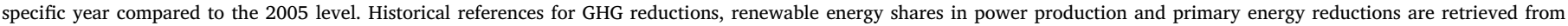

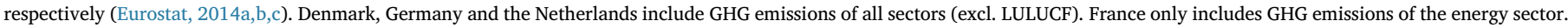

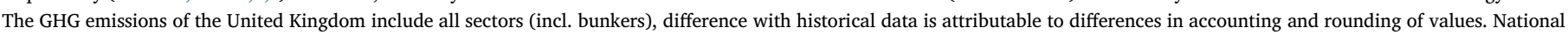

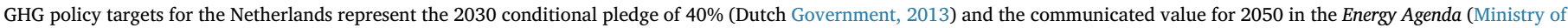
Economic Affairs, 2016).

latter creates major difficulties in comparing primary energy reductions between scenarios with a stronger focus on renewables energy implementation to scenarios that prescribe a greater role to nuclear and CCS.

The EMF28 scenarios provide an alternative perspective to longterm decarbonisation strategies by placing national developments in a broader European context. As the EMF28 scenario studies aim to meet the $80 \%$ GHG emission reduction target on the European level by 2050 - devising effort sharing principles and a dynamic representation of the EU internal market in a more simplified environment ${ }^{5}$ - they are able to cover a wider spectrum of possible long-term strategies than generally studied in the national model-based studies. National preferences and policy objectives seem therefore to narrow the leeway that can be taken

\footnotetext{
${ }^{5}$ Without any explicit representation of the national policy contexts, adopting a uniform scenario narrative over the range of represented EU Member States.
}

into consideration, shifting the focus towards the upper end of the range.

\section{Discussion}

The EU 2030 governance scheme and the long-term national climate and energy plans are intended to provide long-term predictability and certainty to meeting the European objective (European Commission, 2015). However, despite an overall trend of national governments to embrace ambitious policies and legal frameworks, regulatory stability and formalised evaluation routines provide no guarantee that policies remain coherent and consistent over time. This has been relatively recently demonstrated by the UK government, which has shifted the longterm decarbonisation orientation from a focus on all available lowcarbon technologies (as was also modelled in an earlier publication of UKERC (2013)) to the prioritisation, at least in the short-term, of nuclear energy and offshore wind. Hence, although various 
institutionalised legal and non-legal arrangements may secure some direction over time, they do not prevent counterproductive developments and inefficiencies along the way.

Rather than providing long-term predictability, model-based scenario analysis could help push (non)governmental stakeholders in thinking beyond conventional solutions instead (Lempert et al., 2009; Voinov and Bousquet, 2010). Particularly in the light of the observed misalignment of national ambitions with global long-term commitments (Kuramochi et al., 2016; UNEP, 2016) and the uncertainties in the depicted large-scale deployment of several technologies in modelbased scenarios, the ex-ante evaluation processes could drive broader learning on the (un)available necessary change among the modellers, decision-makers and stakeholders. Furthermore, model-based policy evaluation could also provide the first basis for a more coordinated development of policy across Europe. Given the national resolution in the quantitative ex-ante evaluation processes, it may be beneficial for EU Member States to engage in international and structured knowledge exchange (Notenboom et al., 2012). Particular regions whose renewable power supply is expected to exceed national demand soon, or those that depend on biomass imports, may benefit from harmonising assumptions across the national policy studies.

Furthermore, although it is recognised in scholarly literature that participatory processes generate legitimacy and social acceptance for policy choices (Kowarsch, 2016; Scheffran, 2006; van Asselt and Rijkens-Klomp, 2002; Voinov and Bousquet, 2010), we find only limited examples and evaluations of the more formalised applications in practice. By including a broader audience in ex-ante planning and evaluation processes, it can solicit input from a wider range of stakeholders and induce a dialogue that allows for mutual learning. Particularly methods that provide immediate feedback (e.g. on-site interaction between modellers and stakeholders) have been found to yield notable result (as has been demonstrated in France) (Mathy et al., 2015b). Approaches that offer no direct feed-back, such as the My2050 online platform in the UK, have not been considered as effective methods in Allen and Chatterton (2013). In that regard, the current observations would suggest that participatory modelling is a promising method to draw out more robust long-term solutions. Although participatory processes are recognised to have specific challenges - e.g. being regarded as overly complicated, time consuming or impossible, especially in large studies using complex models (Salter et al., 2010; van Vliet et al., 2010) - they should be seen as encouragements to pursue further experience with these methods in national planning and evaluation processes.

\section{Conclusions}

In this study we have looked at how ex-ante policy planning and evaluation processes are practiced in five EU Member States. We have systematically looked at (1) the governance of ex-ante policy planning and evaluation processes and the national arrangement for (2) quantitative (model-based) ex-ante policy evaluation and (3) qualitative exante policy evaluation (stakeholder participation). In a subsequent step we have quantitatively compared two analytical ex-ante evaluation exercises to consider the relative differences across the five EU Member States. We draw out the following insights:

The national long-term policy planning and policy evaluation processes have been organised very differently across the five included Member States

The research revealed that the studied five Member States have organised their long-term planning and evaluation practices very differently. For example, the United Kingdom has institutionalised legally binding (intermediate) objectives with recurring (model-based) evaluation cycles over time. The arrangement allows for adaptive planning which reduces planning uncertainties. France and Denmark show a similar approach by laying down targets in legislation, though reflect a more process-oriented institutional framework. The German government does not have any legal safeguards for their long-term climate ambitions but devises interministerial approval procedures and makes frequent use of model-based scenario analysis for strategic planning purposes. The Netherlands has adopted the European longterm low-carbon ambition in the national policy context, though does not give substance to such ambitions within a clear institutional or procedural framework.

National model-based analyses could be used more effectively in providing analytical support in ex-ante policy evaluation processes

Model-based scenario analyses are extensively used in the studied five Member States to outline possible development over time. They provide analytical decision support and simultaneously reveal the considered policy directions and assumed conditions. However, due to the national resolution of the quantitative ex-ante evaluation processes, all Member States exposed a rather closed-system approach. The study therefore underscores two main areas of improvement in the application of model-based scenario analysis, particularly in the as-is use (technical documentation and knowledge exchange) and extended use (broader application). In regards to the former, multilateral collaboration could improve the ex-ante evaluation process on both the national and European level by exchanging information on cross-border topics such as, amongst others, biomass imports and energy market developments. In regards to the latter, as model-based analyses allow to quickly prototype and assess a variety of futures in a consistent manner, they allow for social learning if used in a wider research perspective. By including a broader policy context or by engaging with stakeholders, ex-ante policy evaluation processes and tools could help strengthen the analytical understanding of required transformative change and subsequently provide a more durable long-term solution over time.

\section{Acknowledgements}

The research leading to these results has received funding from the European Union Seventh Framework Programme FP7/2007-2013 under grant agreement no. 603942 (PATHWAYS). JW has received funding from the UK Research Councils for the UK Energy Research Centre (award no. EP/L024756/1).

\section{References}

ANCRE, 2016. Activity Report 2015-2016.

Allen, P., Chatterton, T., 2013. Carbon reduction scenarios for 2050: an explorative analysis of public preferences. Energy Policy 63, 796-808.

Anandarajah, G., Dessens, O., McGlade, C., 2013. Modelling of Global Energy Scenarios Under Co2 Emissions Pathways With TIAM-UCL.

Argyriou, M., Bataille, C., Colombier, M., Criqui, P., Denis, A., Mathy, S., Sawyer, D., Waisman, H., 2016. The impact of the Deep Decarbonization Pathways Project (DDPP) on domestic decision-making processes - Lessons from three countries, ISSUE BRIEF N(11/16 NOVEMBER 2016 | CLIMATE, Deep Decarbonization Pathways Project - deepdecarbonization.org.

BMUB, 2016. Klimaschutzplan 2050 - Kabinettbeschluss vom 14. November 2016.

BMUB, 2016. Maßnahmenkatalog - ergebnis des Dialogprozesses zum Klimaschutzplan 2050 der Bundersregierung.

Beunderman, M., 2017. Klimaatwet PvdA-GroenLinks krijgt brede steun, NRC, [www] [accessed 26-6-2017] https://www.nrc.nl/nieuws/2017/01/27/klimaatwet6435133-a1543351.

Climate Change Act 2008 (c. 27), 2008. Climate Change Act 2008 - chapter 27.

Comber, N., Sheikh, S., 2011. Evaluation and Learning from the 2050 Public Engagement Programme. Office for Public Management.

Committee on Climate Change, 2016. The Fifth Carbon Budget - The next step towards a low-carbon economy, [www] [accessed 26-06-2017] https://www.theccc.org.uk/ publication/the-fifth-carbon-budget-the-next-step-towards-a-low-carbon-economy/.

DNTE, 2013. Quelle trajectoire pour atteindre le mix énergétique en 2025? Quels types de scénarios possibles à horizons 2030 et 2050, dans le respect des engagements climatiques de la France?.

Daniels, B., Kruitwagen, S., 2010. Referentieraming energie en emissies. pp. 2010-2020.

Danish Energy Agency, 2014. Energy scenarios for 2020, 2035 and 2050.

Dutch Government, 2016. Einde dialoog in zicht, [www] [accessed 17-01-2017] http:// mijnenergie2050.nl/Actueel/563538.aspx.

EC, 2004. Decision No 280/2004/EC of the European Parliament and of the Council of 11 February 2004 concerning a mechanism for monitoring Community greenhouse gas emissions and for implementing the Kyoto Protocol. 
EEA, 2014. Trends and projections in Europe 2014 - Tracking progress towards Europe's climate and energy targets for 2020.

EEA, 2016. National Emissions Reported to the UNFCCC and to the EU Greenhouse Gas Monitoring Mechanism.

European Commission, 2011. Communication from the Commission to the European Parliament, the Council, the European Economic and Social Committee and the Committee of the Regions A Roadmap for Moving to a Competitive Low Carbon Economy in 2050.

European Commission, 2014. Communication from the commission to the European Parliament, the council, the European Economic and Social Committee, the Committee of the regions and the European Investment bank: A policy framework for climate and energy in the period from 2020 to 2030.

European Commission, 2015. COM(2015) 576 Final - Report from the Commission to the European Parliament and the Council - Climate Action Progress Report, Including the Report on the Functioning of the European Carbon Market and the Report on the Review of Directive 2009/31/EC on the Geological Storage of Carbon Dioxide.

European Commission, 2016. Proposal for a regulation of the European Parliament and of the Council on the Governance of the Energy Union COM(2016) 759 final.

European Union, 2009. Decision No 406/2009/EC of the European Parliament and of the Council of 23 April 2009 on the effort of Member States to reduce their greenhouse gas emissions to meet the Community's greenhouse gas emission reduction commitments up to 2020

European Union, 2009. Directive 2009/28/EC of the European Parliament and of the Council of 23 April 2009 on the promotion of the use of energy from renewable sources and amending and subsequently repealing Directives 2001/77/EC and 2003/ 30/EC.

European Union, 2009. Directive 2009/29/EC of the European Parliament and of the Council of 23 April 2009 amending Directive 2003/87/EC so as to improve and extend the greenhouse gas emission allowance trading scheme of the Community.

European Union, 2013. Regulation (EU) No 525/2013 of the European Parliament and of the Council of 21 May 2013 on a mechanism for monitoring and reporting greenhouse gas emissions and for reporting other information at national and Union level relevant to climate change and repealing Decision No 280/2004/EC Text with EEA relevance. Offic. J. Eur. Union L 165 (18 June 2013).

Eurostat, 2014. Electricity generated from renewable sources - \% of gross electricity consumption, [www][Accessed 23-03-2017] http://ec.europa.eu/eurostat/tgm/ table. do $?$ tab $=$ table\&init $=1$ \&plugin $=1$ \&language $=$ en\&pcode $=$ tsdcc 330 .

Eurostat, 2014. Greenhouse gas emissions by sector (source: EEA) - million tonnes of CO2 equivalent, [www] [Accessed 23-03-2017] http://ec.europa.eu/eurostat/tgm/ table. do tab $=$ table\&init $=1$ \&language $=$ en \&pcode $=$ tsdcc 210 \&plugin $=1$.

Eurostat, 2014. Primary production of energy by resource -1000 tonnes of oil equivalent, [www] [Accessed 23-03-2017] http://ec.europa.eu/eurostat/tgm/table. do $?$ tab $=$ table\&init $=1 \&$ language $=$ en\&pcode $=$ ten $00076 \&$ plugin $=1$.

Faber, A., de Goede, P.J.M., Weijnen, M.P.C., 2016. Long-term Commitment for National Climate Policy in the Netherlands. WRR-Policy Brief No. 5. WRR, The Hague.

Fabra, N., Matthes, F.C., Newbery, D., Colombier, M., Mathieu, M., Rüdinger, A., 2015 The energy transition in Europe: Initial lessons from Germany, the UK and France. [online] [Accessed 03-02-2017] http://www.cerre.eu/sites/cerre/files/151006 CERREStudy_EnergyTransition_Final.pdf.

Gas Unie, 2016. Verkenning 2050 - Discussiestuk.

Dutch Government, 2013. Klimaatagenda: voorkomen, aanpassen en ondernemen, [www][Accessed 26-6-2017] https://www.rijksoverheid.nl/actueel/nieuws/2013/ 10/04/klimaatagenda-voorkomen-aanpassen-en-ondernemen.

Grandjean, A., Blanchet, E., Finidori, E., 2014. Étude des 4 tranjectoires du DNTE - Une vision pédagogique des 4 trajectoires étudiées dans le cadre de débat national sur la transition energétique.

Haller, M., Repenning, J., Vogel, M., Schlomanhn, B., Reuter, M., Jochem, E., Reitze, F., Schon, M., Toro, F., 2015. Überblick über vorliegende Szenarienarbeiten für den Klimaschutz in Deutschland bis 2050, Öko-Institut e.V., Fraunhofer Institut für System- und Innovationsforschung, IREES GmbH (Institut für Ressourceneffizienz und Energiestrategien).

Hillebrandt, K., Samadi, S., Fischedick, M., Eckstein, S., Höller, S., Janßen, T., Kamps, K., Krüger, C., Lechtenböhmer, S., Nigge, G., Pastowski, A., Sellke, P., 2015. Pathways to Deep Decarbonization in Germany. SDSN - IDDRI.

Hovi, J., Sprinz, D.F., Underdal, A., 2009. Implementing long-term climate policy: time inconsistency, domestic politics, international anarchy. Glob. Environ. Polit. 9 , 20-39.

Janssen, L.H.J.M., Okkes, V.R., Schuur, J., 2006. Welvaart en Leefomgeving: een scenariostudie voor Nederland in 2040, Centraal Planbureau, Milieu - en Natuurplanbureau en Ruimtelijk Planbureau.

Jordan, A.J., Liefferink, D., 2004. Environmental Policy in Europe: the Europeanization of National Environmental Policy. Routledge.

Knopf, B., Chen, Y.-H.H., De Cian, E., Förster, H., Kanudia, A., Karkatsouli, I., Keppo, I., Koljonen, T., Schumacher, K., Van Vuuren, D.P., 2013. Beyond 2020—strategies and costs for transforming the European energy system. Climate Change Econ. 4, 1340001.

Kowarsch, M., 2016. Elements of a Guideline for Future Integrated Economic Assessments of the IPCC, A Pragmatist Orientation for the Social Sciences in Climate Policy: How to Make Integrated Economic Assessments Serve Society. Springer International Publishing, Cham, pp. 275-299.

Kuramochi, T., Höhne, N., Gonzales-Zuñiga, S., Hans, F., Sterl, S., Hagemann, M., HernandezLegaria, E., den Elzen, M., Roelfsema, M., van Soest, H., Forsell, N., Turkovska, O., 2016. Greenhouse Gas Mitigation Scenarios for Major Emitting Countries. Analysis of Current Climate Policies and Mitigation Pledges.

Lempert, R., Scheffran, J., Sprinz, D.F., 2009. Methods for long-term environmental policy challenges. Methods 9.

Lund, H., Mathiesen, B.V., 2009. Energy system analysis of 100\% renewable energy systems-the case of Denmark in years 2030 and 2050. Energy 34, 524-531.

Lund, H., Hvelplund, F., Mathiesen, B.V., Ostergaard, P.A., Christensen, P., Connolly, D., Schaltz, E., Pollay, J.R., Nielsen, M.P., Felby, C., Bentsen, N.S., Meyer, N.I., Tonini, D., Astrup, T., Heussen, K., Morthorst, P.E., Andersen, F.M., Münster, M., Hansen, L.P., Wenzel, H., Hamelin, L., Munksgaard, J., Karnoe, P., Lind, M., 2011. Coherent Energy and Environmental System Analysis.

Manders, T., Kool, C., 2015. Toekomstverkenning Welvaart en Leefomgeving. Nederland in 2030 en 2050: twee referentiescenario's, Den Haag : Planbureau voor de Leefomgeving/Centraal Planbureau.

Mathiesen, B.V., Lund, H., Hansen, K., Skov, I.R., Djørup, S.R., Nielsen, S., Sorknæs, P., Thellufsen, J.Z., Grundahl, L., Lund, R.S., Drysdale, D.W., Connolly, D., Østergaard, P.A., 2015. IDA's Energy Vision 2050: A Smart Energy System strategy for 100\% renewable Denmark.

Mathy, S., Criqui, P., Hourcade, J.C., 2015. Pathways to Deep Decarbonization in 2050 in France. The French report of the Deep Decarbonization Pathways Project of the Sustainable Development Solutions Network and the Institute for Sustainable Development and International Relations.

Mathy, S., Fink, M., Bibas, R., 2015b. Rethinking the role of scenarios: participatory scripting of low-carbon scenarios for France. Energy Policy 77, 176-190.

Matthijsen, J., Aalbers, R., van den Wijngaart, R., 2015. Toekomstverkenning Welvaart en Leefomgeving - Cahier Klimaat en Energie. CPB/PBL.

McGlade, C., Pye, S., Watson, J., Bradshaw, M., Ekins, P., 2016. The Future Role of Natural Gas in the UK, Research Report. UK Energy Research Centre, London.

Ministry of Ecology Sustainable Development and Energy, 2015a. Energy Transition for the Green Growth act.

Ministry of Ecology Sustainable Development and Energy, 2015b. Stratégie Nationale Bas-Carbone.

Ministry of Economic Affairs, 2016. Energieagenda: Naar een CO2-arme energievoorziening, [www][Accessed 26-6-2017] https://www.rijksoverheid.nl/ documenten/rapporten/2016/12/07/ea.

Nilsson, M., Jordan, A., Turnpenny, J., Hertin, J., Nykvist, B., Russel, D., 2008. The use and non-use of policy appraisal tools in public policy making: an analysis of three European countries and the European Union. Policy Sci. 41, 335-355.

Notenboom, J., Boot, P., Koelemeijer, R., Ros, J., 2012. Climate and Energy Roadmaps Towards 2050 in North-West Europe: A Concise Overview of Long-Term Climate and Energy Policies in Belgium, Denmark, France, Germany, the Netherlands and the United Kingdom. PBL Netherlands Environmental Assessment Agency., The Hague.

Öko-Institut/Fraunhofer ISI, 2014. Klimaschutzszenario 2050. 1. Modellierungsrunde.

Öko-Institut;/Fraunhofer ISI, 2015. Klimaschutzszenario 2050 - 2. Runde.

Öko-Institut/Fraunhofer ISI, 2016. Klimaschutzszenario 2050: Zusammenfassung des 2. Endberichts Studie im Auftrag des Bundesministeriums für Umwelt, Naturschutz, Bau und Reaktorsicherheit.

PBL/ECN, 2011. Naar Een Schone Economie in 2050:routes Verkend. Hoe Nederland Klimaatneutraal Kan Worden. PBL Netherlands Environmental Assessment Agency, The Hague([www][Accessed 26-06-2017] http://www.pbl.nl/sites/default/files/ cms/publicaties/PBL-2011-Routekaart-energie-2050-500083014.pdf).

Pye, S., Anandarajah, G., Fais, B., McGlade, C., Strachan, N., 2015. Pathways to Deep Decarbonization in the United Kingdom.Pathways to Deep Decarbonization in the United Kingdom.

Sørensen, P.B., Elmeskov, J., Frederiksen, P., Jacobsen, J.B., Kristensen, N.B., Morthorst, P.E., Richardson, K., 2015. Converting with Care - Status and Challenges for Danish Climate Policy.

Salter, J., Robinson, J., Wiek, A., 2010. Participatory methods of integrated assessment-a review. Wiley Interdiscip. Rev. Clim. Change 1, 697-717.

Sartor, O., Donat, L., Duwe, M., Umpfenbach, K., 2017. Developing 2050 Decarbonization Strategies in the EU: Insights on Good Practice from National Experiences, Study n (03/2017. IDDRI, Paris France (22 p.).

Scheffran, J., 2006. Tools for Stakeholder Assessment and Interaction. Stakeholder Dialogues in Natural Resources Management. pp. 153-185.

Schoots, K., Hekkenberg, M., Hammingh, P., 2016. Nationale Energieverkenning. ECN-O16-035. Energieonderzoek Centrum Nederland, Petten.

Strachan, N., 2011a. UK energy policy ambition and UK energy modelling-fit for purpose? Energy Policy 39, 1037-1040.

Strachan, N., 2011b. UKERC Energy Research Landscape: Energy Systems Modelling.

UKERC, 2013. The UK. energy system in 2050: Comparing Low-Carbon Resilient Scenarios.

UNEP, 2016. The Emissions Gap Report 2016 - The UNEP Synthesis Report, Nairobi.

van Asselt, M.B.A., Rijkens-Klomp, N., 2002. A look in the mirror: reflection on participation in Integrated Assessment from a methodological perspective. Global Environ. Change 12, 167-184.

van Sluisveld, M.A.E., Boot, P., Hammingh, P., Notenboom, J., van Vuuren, D.P., 2016. Low-carbon Energy Scenarios in North-west European Countries - Report of the PBI Round-table of June 10th, 2016. PBL Netherlands Environmental Assessment Agency.

van Vliet, M., Kok, K., Veldkamp, T., 2010. Linking stakeholders and modellers in scenario studies: the use of Fuzzy Cognitive Maps as a communication and learning tool. Futures 42, 1-14.

Voinov, A., Bousquet, F., 2010. Modelling with stakeholders. Environ. Modell. Softw. 25, 1268-1281.

Wei, Y.-M., Mi, Z.-F., Huang, Z., 2015. Climate policy modeling: an online SCI-E and SSCI based literature review. Omega 57, 70-84.

Weyant, J., Knopf, B., De Cian, E., Keppo, I., van Vuuren, D.P., 2013. Introduction to the EMF28 study on scenarios for transforming the European energy system. Climate Change Econ. 4, 1302001. 